\title{
Social influences on birth weight
}

\section{N Spencer, S Logan}

\section{Risk factors for low birth weight are strongly influenced by the social environment}

B irth weight, like growth, is determined by the complex interplay of genetic and environmental factors. The proportional contribution of these influences is unclear. However, birth weight varies within genetically similar populations, ${ }^{1-3}$ suggesting that environmental factors play a significant role. Secular changes in birth weight ${ }^{4}$ also suggest an environmental influence. Birth weight also shows a reverse social gradient such that increasing disadvantage is associated with decreasing birth weight. ${ }^{1-3}$

\section{ENVIRONMENTAL FACTORS AFFECTING BIRTH WEIGHT}

Environmental factors with a known association with birth weight are nutrition, smoking, maternal ill health, and genital infection. The association of other factors such as stress ${ }^{5}$ and exposure to some types of work during pregnancy $^{6}$ remains unproven. Other risk factors for low birth weight such as maternal age, although not themselves environmental factors, are strongly influenced by the social environment.

Severe energy restriction during pregnancy, such as occurs in some developing countries $^{7}$ and was noted in the 1945 Dutch Hunger Winter ${ }^{8}$, reduces birth weight but, randomised controlled trials of nutritional interventions in the index pregnancy have failed to show convincing benefit.' Nutrition may exert its effect over a longer period through an effect on maternal growth in childhood ${ }^{10}$ and possibly through an intergenerational effect. ${ }^{11}$ Adult height has a known association with relative nutritional impairment in childhood, ${ }^{12}$ and maternal height is an important determinant of birth weight. ${ }^{13}$

The association of smoking with a reduction in birth weight is well established. ${ }^{13}$ Maternal ill health has been associated with reduced birth weight, ${ }^{14}$ and genital infection exerts its influence through increasing the risk of preterm delivery. ${ }^{15}$

This article is reproduced in full with permission of Arch Dis Child Fetal Neonatal Ed 2002; 86:F6-7.
Evidence for an independent effect of stress is slight, but one study does show stress exerting an effect through increased smoking. ${ }^{16}$

\section{SOCIAL GRADIENT IN BIRTH WEIGHT}

Given the importance of birth weight for infant, childhood, and adult health, ${ }^{17}$ a 150-200 g social gradient in mean birth weight and $30 \%$ of births less than 2500 $\mathrm{g}$ attributable to social inequalities ${ }^{1}$ is a key public health issue. Reductions in inequalities in infant mortality and many childhood and adult health inequalities, key government health targets, $^{18}$ are unlikely to be achieved without a narrowing of the social gradient in birth weight. Interventions to increase birth weight in disadvantaged groups have been largely unsuccessful, ${ }^{19}$ and, although mean birth weight has increased, ${ }^{20}$ the rate of change is slow and the gradient remains unchanged.

\section{"Reductions in inequalities in infant mortality and many childhood and adult health inequalities, key government health targets, are unlikely to be achieved without a narrowing of the social gradient in birth weight."}

The failure of interventions to influence the social gradient is likely to result from a focus on modifying individual risk factors such as smoking, diet, and infection in the already established pregnancy with the intervention starting around 16 weeks at the earliest. The social gradient in birth weight probably arises as a result of the accumulation and addition of risk and protective factors over time ${ }^{21}$ and across generations ${ }^{11}$ rather than resulting from risk exposures within the index pregnancy. Poor socioeconomic circumstances in early life may lead to biological vulnerability in later life, ${ }^{22}$ and adult health behaviours seem to have socioeconomic roots early in life. ${ }^{23}$ A woman whose parents were disadvantaged is more likely to have been low birth weight herself, to have experienced more childhood ill health, to have had a less nutritious diet with adverse effect on her growth, to have started smoking in adolescence and be less likely to quit in early pregnancy, and to come to pregnancy at an earlier age.

Although innovative approaches to smoking cessation and stress reduction may have some effect in the short term, reduction of the social gradient is likely to be a long term goal requiring attention to the nutritional and health status of young children. Of equal importance will be improving the overall social environment in which children grow up so that protective factors, such as maternal education, become more evenly distributed across social groups and risk factors are reduced in disadvantaged groups.

\section{J Epidemiol Community Health} 2002;56:326-327

\section{Authors' affiliations}

N Spencer, Department of Child Health, School of Postgraduate Medical Education and School of Health and Social Studies, University of Warwick, Coventry CV4 7AL, UK

$S$ Logan, Department of Epidemiology and Biostatistics, Institute of Child Health, London, UK

Correspondence to: Professor Spencer; n.j.spencer@warwick.ac.uk

\section{REFERENCES}

1 Spencer NJ, Bambang S, Logan S, et al. Socio-economic status and birth weight: comparison of an area-based measure with the Registrar General's social class. J Epidemiol Community Health 1999:53:495-8.

2 Elmen $\mathbf{H}$, Hoglund D, Karlberg $P$, et al. Birth weight for gestational age as a health indicator: birth weight and mortality measures at a local level. Eur J Public Health 1996:6:137-41.

3 Mackenbach JP. Socio-economic health differences in the Netherlands: a review of recent empirical findings. Soc Sci Med 1992;34:213-26.

4 Power C. National trends in birth weight: implications for future adult disease. $B M$ 1994;308: 1270-1

5 Hoffman S, Hatch MC. Stress, social support and pregnancy outcome: a reassessment based on recent research. Paediatr Perinat Epidemiol 1996; 10:380-405.

6 Homer CJ, James SA, Siegel E. Work-related psychosocial stress and risk of preterm, low birth weight delivery. Am J Public Health 1989:80:173-7.

7 Achadi EL, Hansell M, Sloan NL, et al. Women's nutritional status, iron consumption and weight gain during pregnancy in relation to neonatal weight and length in West Java, Indonesia. Int J Gynaecol Obstet 1995;48(suppl):S103-19.

8 Hart N. Famine, maternal nutrition and infan mortality: a re-examination of the Dutch Hunger Winter. Popul Stud (Camb) 1993:47:27-46.

9 Kramer MS. Balanced protein/energy supplementation in pregnancy (Cochrane Review). In: Cochrane Library, Issue 4, 1998.

10 Baird D. Environment and reproduction. $\mathrm{Br} J$ Obstet Gynaecol 1980;87: 1057-67. 
11 Emanuel I, Filakti $\mathrm{H}$, Alberman $\mathrm{E}$, et al. Intergenerational studies of human birth weight from the 1958 birth cohort. 1 . Evidence for a multigenerational effect. $\mathrm{Br} J$ Obstet Gynaecol 1992;99:67-74.

12 Berney L, Blane D, Davey Smith G, et al. Lifecourse influences on health in early old age. In: Graham H, ed. Understanding health inequalities. Buckingham and Philadelphia: Open University Press, 2000.

13 Kramer MS. Determinants of low birth weight: methodological assessment and meta-analysis. Bull WHO 1987;65:666-737.

14 Baird D. The epidemiology of low birth weight: changes in incidence in Aberdeen, 1948-72. J Biosoc Sci 1974;6:623-41.
15 Divers MJ, Lilford RJ. Infection and preterm labour: a meta-analysis. Contemporary Reviews of Obstetrics and Gynaecology 1993:5:71-84.

16 Sheehan TJ. Stress and low birth weight: a structural modeling approach using real life stressors. Soc Sci Med 1998;47: 1503-12.

17 Barker DJP, ed. Fetal and infant origins of adult disease. London : BM Publications Group, 1992.

18 Department of Health. Health Inequalities: Health Secretary announces new plans to improve health in poorest areas: 28th February, 2001. http://www.doh.gov.uk/ healthinequalities/press.htm.
19 Paneth NS. The problem of low birth weight. The Future of Children 1995;5:20-32.

20 Alberman E. Are our babies becoming bigger? J R Soc Med 1991;84:257-60.

21 Kuh D, Power C, Blane D, et al. Social pathways between childhood and adult health. In: Kuh D and Ben-Shlomo Y, eds. A life course approach to chronic disease epidemiology Oxford: Oxford Medical Publications, 1997

22 Wadsworth MEJ. Health inequalities in the life course perspective. Soc Sci Med 1997;44:859-69.

23 Lynch JW, Kaplan GA, Salonen JT. Why do poor people behave poorly? Variation in adult health behaviours and psychosocial characteristics by stages of the socioeconomic lifecourse. Soc Sci Med 1997;44:809-19.

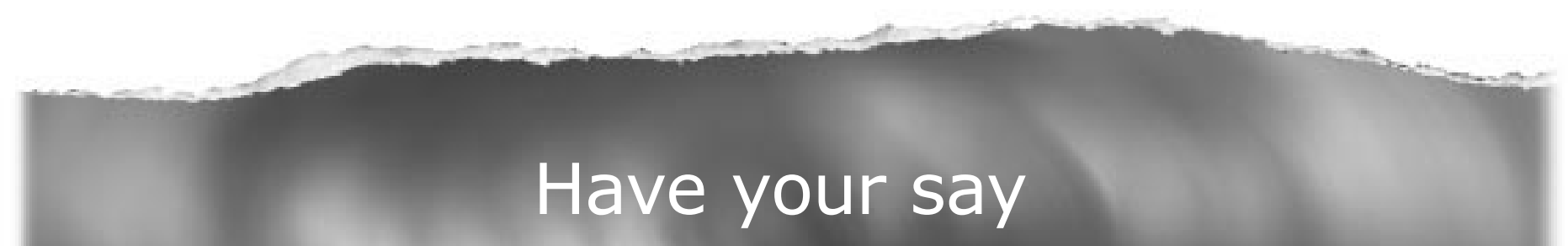

\section{eLetters}

If you wish to comment on any article published in the Journal of Epidemiology and Community Health you

can send an eletter using the eLetters link at the beginning of each article. Your response will be posted on Journal of Epidemiology and Community Health online within a few days of receipt (subject to editorial screening).

\section{www.jech.com}

